\title{
Efektivitas Handout pada Pembelajaran Kimia dalam Meningkatkan Prestasi Siswa: Review
}

\author{
Venanda Risma Kurnia Ayu \\ Pendidikan Kimia, Universitas Negeri Surabaya \\ Email: venanda.17030194079@mhs.unesa.ac.id \\ Rinaningsih Rinaningsih \\ Pendidikan Kimia, Universitas Negeri Surabaya \\ Email: rinaningsih@unesa.ac.id
}

(Diterima: 4-Januari-2021; direvisi: 5-Februari-2021; dipublikasikan: 22-Maret-2021)

\begin{abstract}
Abstrak: Penelitian ini bertujuan untuk menganalisis efektivitas handout sebagai alternatif pembelajaran kimia dalam meningkatkan prestasi siswa. Metode yang digunakan pada artikel ini adalah meta analisis dari beberapa literatur yang relevan dengan topik dan tujuan penelitian. Handout diidentifikasi memiliki tingkat kepraktisan yang optimal, serta dinilai efektif untuk diaplikasikan kepada siswa karena dapat mempermudah siswa dalam proses pembelajaran. Peran guru dalam metode ini lebih kepada penguatan materi dengan memberikan pemahaman mengenai materi yang kurang tepat yang disampaikan kelompok. Guru bersama siswa menyimpulkan hasil yang didapatkan dan dilakukan penilaian untuk mengetahui tingkat ketercapaian siklus I. Tahap selanjutnya pada siklus II asisten kelompok diharapakan memberikan pemahaman kepada siswa lain, sehingga terjadi interaksi antar siswa yang diidentifikasi berkontribusi pada hasil penilaian siklus II. Hasilnya terdapat peningkatan ketercapaian siswa dalam aspek kognitif maupun afektif dimana aspek kognitif yang sebelumnya berada pada tingkat ketercapaian 42,11\% meningkat menjadi $63,16 \%$ melebihi target $60 \%$. Sementara pada aspek afektif meningkat dari $70,24 \%$ menjadi $74,47 \%$. Perpaduan metode diskusi dan penggunaan handout serta video sebagai media pembelajaran dapat meningkatkan hasil belajar atau prestasi siswa dengan lebih efektif.
\end{abstract}

Kata kunci: Handout; Kimia; Prestasi; Siswa.

Abstract: This study aims to analyze the effectiveness of handouts as an alternative to learning chemistry in improving student achievement. The method used in this article is a meta-analysis of several pieces of literature relevant to the topic and research objectives. The handout was identified as having an optimal level of practicality, and was considered adequate for students because it made it easier for students in the learning process. The teacher's role in this method is more to strengthen the material by providing an understanding of the inappropriate material delivered by the group. The teacher and the students concluded the results obtained, and an assessment was carried out to determine the level of achievement of the cycle I. In the next stage in cycle II, the group assistants were expected to understand other students so that interactions between students were identified as contributing to the second cycle assessment results. The result is an increase in student achievement in both cognitive and affective aspects. The cognitive aspects previously at the level of achievement of $42.11 \%$ increased to $63.16 \%$ exceeding $60 \%$. Meanwhile, the affective aspect increased from $70.24 \%$ to $74.47 \%$. The combination of discussion methods and handouts, and also videos as learning media can improve student learning outcomes or student achievement more effectively. 
Keywords: Handout; Chemical; Achievement; Student.

\section{PENDAHULUAN}

Pendidikan diidentifikasi sebagai salah satu usaha yang dapat dilakukan untuk meningkatkan kualitas Sumber Daya Manusia (SDM) (Yusutria, 2017). SDM dengan kualitas tinggi dinilai akan lebih siap dan lebih mampu dalam menghadapi tantangan zaman yang semakin kuat. Pendidikan merupakan suatu modal yang dapat dimanfaatkan untuk membangun SDM yang kompeten dan unggul di bidang masing-masing, melalui pembenahan dan pembaharuan pada sistem pendidikan (Saufi \& Hambali, 2019) Hal ini juga tidak bisa lepas dari sistem pembelajaran sebagai salah satu komponen dalam pendidikan.

Pembelajaran dinilai sebagai sarana dalam memicu berkembangnya kemampuan berpikir kritis dan analitik siswa yang juga didasarkan pada aspek psikomotor dan afektif siswa (Rahma, 2012). Oleh karena itu, tidak jarang ditemui berbagai metode pembelajaran dan penggunaan bahan ajar yang diciptakan untuk menstimulasi siswa agar memiliki minat yang positif dalam kegiatan belajar mengajar dan mampu membawa implikasi positif pula terhadap pola berpikir siswa, hasil belajar dan prestasi yang dicapai.

Kimia diidentifikasi sebagai salah satu keilmuan yang memiliki kompleksitas tinggi (Jayadiningrat \& Ati, 2018). Penguasaan keterampilan serta penalaran secara saintifik dibutuhkan untuk dapat memahami konsep dalam pembelajaran kimia. Realita di lapangan seringkali mendapatkan termuan adanya persepsi berbeda oleh siswa mengenai pembelajaran kimia. Siswa cenderung menganggap kimia adalah salah satu pelajaran yang rumit, susah dan tidak menarik (Norjana \& Joharmawan, 2016) dan (Sulastry \& Jusniar, 2011). Fakta ini perlu diluruskan, salah satunya melalui penggunaan bahan ajar kimia yang inovatif, menarik dan mampu memenuhi kebutuhan siswa sekaligus sesuai dengan kurikulum dan kompetensi yang diterapkan. Penggunaan bahan ajar diidentifikasi sebagai salah satu upaya yang dapat dilakukan untuk meningkatkan minat siswa dalam berpartisipasi aktif terhadap pembelajaran. Hal ini disebabkan bahan ajar dinilai memiliki urgensi yang cukup tinggi dalam upaya meningkatkan keberhasilan proses pembelajaran yang berlangsung (Lubis \& Ikhsan, 2015). Handout merupakan salah satu bentuk bahan ajar yang dapat diaplikasikan pada pembelajaran kimia.

Handout dipilih karena memiliki tingkat kepraktisan yang optimal (Yerimadesi, Bayharti, et al., 2017) (L. Wati \& Fatisa, 2018) (Septryanesti \& Lazulva, 2019). Handout juga dinilai efektif untuk diaplikasikan kepada siswa karena dapat mempermudah siswa dalam proses pembelajaran (Herawati \& Muhtadi, 2018). Kolaborasi dari ketiga hal ini dapat dinilai sebagai kelebihan handout sebagai bahan ajar. Kemudahan untuk memahami materi atau konsep yang didapatkan melalui penggunaan handout sebagai bahan ajar dapat memicu peningkatan minat belajar siswa (Sulastri et al., 2018) serta frekuensi aktivitas belajar siswa (Agustina et al., 2013) (Salfrika, 2016).

Tingginya minat belajar yang diimbangi dengan kenaikan frekuensi belajar siswa berkontribusi pada peningkatan kemampuan siswa dalam memahami konsep dan isi (Muwarni et al., 2015) serta kemampuan berpikir kritis (Cahyanto et al., 2016). Hal ini mendorong tercapainya peningkatan belajar siswa (Rinaningsih et al., 2016) (Yerimadesi, Putra, et al., 2017) (Humaira et al., 2019) (S. A. Sari \& Putri, 2020) (Shofwunnada, 2018) (S. A. Sari, 2018) yang lebih tinggi jika dibandingkan pembelajaran tanpa menggunakan handout sebagai bahan ajar. Adanya peningkatan hasil belajar siswa diidentifikasi berkorelasi dengan peningkatan prestasi siswa. Hal ini dibuktikan dengan adanya kenaikan pretasi belajar siswa melalui penggunaan handout sebagai bahan ajar kimia (Cahyanto et al., 2016) (Muwarni et al., 2015) (Rachmatia et 
al., 2016) (Astuti et al., 2016) (Islamic et al., 2016), yang ditandai dengan peningkatan pretasi siswa baik secara kognitif, afektif maupun psikomotor.

Berdasarkan jabaran di atas, diketahui bahwa handout dapat digunakan sebagai alternatif penunjang pembelajaran kimia melalui hasil identifikasi pada beberapa aspek yang mengalami peningkatan. Tujuan dari artikel ini adalah untuk menganalisis efektivitas handout sebagai alternatif pembelajaran kimia dalam meningkatkan prestasi siswa.

\section{METODE}

Artikel ini ditulis berdasarkan jenis literature review menggunakan metode meta analisis, yakni metode penggabungan berbagai artikel dengan tujuan dan hasil studi yang relevan untuk dilakukan identifikasi dan analisis secara sistematis. Artikel pada penelitian ini diperoleh melalui berbagai sumber seperti Google Scholar dan Science Direct menggunakan kata kunci yang sesuai dengan tujuan pada artikel ini. Artikel yang diperoleh kemudian akan diklasifikasikan sesuai dengan hasil dan temuan, untuk kemudian diangkat dan diulas kembali secara sistematis pada artikel ini.

\section{HASIL DAN PEMBAHASAN}

Penggunaan handout bagi siswa pada mata pelajaran bertujuan untuk meningkatkan pemahaman siswa mengenai materi sehingga dapat memberikan hasil belajar yang sesuai dengan target pembelajaran (Azmy et al., 2018; Irfandi et al., 2018) (Subiyanto \& Siregar, 2018) (Fatma et al., 2016) (Habibati et al., 2019) (Zulvianda et al., 2016). Hasil tersebut didapatkan apabila handout yang digunakan mampu memadukan keinginan siswa dan guru sehingga akan meningkatkan minat siswa dalam belajar dengan menggunakan handout tersebut (H. Ulya et al., 2018) (R. Ulya et al., 2016). Minat yang tinggi dari siswa untuk belajar akan memberikan kemungkinan lebih tinggi bagi siswa untuk dapat memahami pelajaran dengan baik disebabkan kuantitas waktu yang digunakan untuk belajar akan lebih tinggi dibandingkan dengan siswa yang kurang berminat (Bhabiet et al., 2018) (Tiring et al., 2015). Kondisi tersebut akan berdampak pada peningkatkan prestasi belajar siswa dalam berbagai aspek mulai dari aspek kognitif, afektif, dan psikomotorik.

Terdapat empat artikel dalam penelitian ini yang digunakan sebagai artikel utama. Artikel tersebut merupakan penelitian yang dilakukan Andre Reza Islamic, J.S. Sukardjo, dan Nanik Dwi Nurhayati (2016) (Islamic et al., 2016); Enggar Mawarni, Bakti Mulyani, dan Sri Yamtinah (2015) (Muwarni et al., 2015); Muhammad Agung Safari Cahyanto, Suryadi Budi Utomo, dan Sri Yamtinah (2016) (Cahyanto et al., 2016); dan Erna Agustina, Agung Nugroho, dan Sri Mulyani (2013) (Agustina et al., 2013). Hasil penelitian dari keempat artikel tersebut dapat dilihat pada Tabel 1.

Tabel 1. Hasil Penelitian Artikel Utama

\begin{tabular}{|c|c|c|c|c|c|c|c|}
\hline \multirow{2}{*}{ Peneliti } & \multirow{2}{*}{$\begin{array}{c}\text { Target } \\
\text { Ketercapaian }\end{array}$} & \multicolumn{3}{|c|}{ Siklus I } & \multicolumn{3}{|c|}{ Siklus II } \\
\hline & & Kognitif & Afektif & Psikomotorik & Kognitif & Afektif & Psikomotorik \\
\hline $\begin{array}{l}\text { Andre Reza } \\
\text { Islamic, J.S. } \\
\text { Sukardjo, } \\
\text { dan Nanik } \\
\text { Dwi } \\
\text { Nurhayati } \\
\text { (2016) }\end{array}$ & $60 \%$ & $\begin{array}{c}42,11 \% \\
\text { (Belum } \\
\text { Berhasil) }\end{array}$ & $\begin{array}{l}70,24 \% \\
\text { (Berhasil) }\end{array}$ & & $\begin{array}{c}63,16 \% \\
\text { (Berhasil) }\end{array}$ & $\begin{array}{l}74,47 \% \\
\text { (Berhasil) }\end{array}$ & \\
\hline $\begin{array}{l}\text { Enggar } \\
\text { Mawarni, } \\
\text { Bakti } \\
\text { Mulyani, }\end{array}$ & $\begin{array}{l}\text { Pada siklus } \\
\text { I 75\% } \\
\text { (kognitif } \\
\text { dan afektif) }\end{array}$ & $\begin{array}{c}58 \% \\
\text { (Belum } \\
\text { Berhasil) }\end{array}$ & $\begin{array}{c}71 \% \\
\text { (Belum } \\
\text { Berhasil) }\end{array}$ & & $\begin{array}{c}83 \% \\
\text { (Berhasil) }\end{array}$ & $\begin{array}{c}100 \% \\
\text { (Berhasil) }\end{array}$ & \\
\hline
\end{tabular}




\begin{tabular}{|c|c|c|c|c|c|c|c|}
\hline \multirow{2}{*}{ Peneliti } & \multirow{2}{*}{$\begin{array}{c}\text { Target } \\
\text { Ketercapaian }\end{array}$} & \multicolumn{3}{|c|}{ Siklus I } & \multicolumn{3}{|c|}{ Siklus II } \\
\hline & & Kognitif & Afektif & Psikomotorik & Kognitif & Afektif & Psikomotorik \\
\hline $\begin{array}{l}\text { dan Sri } \\
\text { Yamtinah } \\
\text { (2015) }\end{array}$ & $\begin{array}{l}\text { Pada siklus } \\
\text { II 75\% pada } \\
\text { aspek } \\
\text { kognitif dan } \\
80 \% \text { pad } \\
\text { aspek } \\
\text { afektif } \\
\end{array}$ & & & & & & \\
\hline $\begin{array}{l}\text { Muhammad } \\
\text { Agung } \\
\text { Safari } \\
\text { Cahyanto, } \\
\text { Suryadi } \\
\text { Budi Utomo, } \\
\text { dan Sri } \\
\text { Yamtinah } \\
\text { (2016) }\end{array}$ & $75 \%$ & $\begin{array}{c}65,63 \% \\
\text { (Belum } \\
\text { Berhasil) }\end{array}$ & $\begin{array}{l}81,65 \% \\
\text { (Berhasil) }\end{array}$ & $\begin{array}{l}87,15 \% \\
\text { (Berhasil) }\end{array}$ & $\begin{array}{c}78,13 \% \\
\text { (Berhasil) }\end{array}$ & $\begin{array}{l}81,65 \% \\
\text { (Berhasil) }\end{array}$ & $\begin{array}{l}87,15 \% \\
\text { (Berhasil) }\end{array}$ \\
\hline $\begin{array}{l}\text { Erna } \\
\text { Agustina, } \\
\text { Agung } \\
\text { Nugroho, } \\
\text { dan Sri } \\
\text { Mulyani } \\
\text { (2013) }\end{array}$ & $70 \%$ & $\begin{array}{c}27,78 \% \\
\text { (Belum } \\
\text { Berhasil) }\end{array}$ & $\begin{array}{c}68,92 \% \\
\text { (Belum } \\
\text { Berhasil) }\end{array}$ & & $\begin{array}{c}77,78 \% \\
\text { (Berhasil) }\end{array}$ & $\begin{array}{l}77,56 \% \\
\text { (Berhasil) }\end{array}$ & \\
\hline
\end{tabular}

Hasil pada Tabel 1 mengacu pada target keberhasilan minimal pada masingmasing penelitian berbeda-beda dan berada pada rentang $60-80 \%$. Berdasarkan tabel 1 menunjukkan bahwa aspek kognitif pada keempat penelitian berada dalam kriteria belum berhasil, karena tingkat ketercapaian aspek kognitif berada pada angka kurang dari $75 \%$ pada siklus I. Angka tersebut kemudian mengalami peningkatan pada siklus II, sehingga secara keseluruhan handout yang dihasilkan dari keempat penelitian tersebut masuk dalam kriteria berhasil. Sementara itu pada aspek afektif, hasil penelitian menunjukkan bahwa dari empat penelitian terdapat dua penelitian yang masuk dalam kriteria berhasil pada siklus I dan dua lainnya masuk dalam kategori tidak berhasil. Pada siklus II penilaian aspek afektif menunjukkan bahwa empat penelitian secara keseluruhan menunjukkan nilai berhasil. Arinya keempat penelitian tersebut telah mampu memberikan hasil melebihi target yang telah ditetapkan. Hasil penelitian pada aspek psikomotorik hanya terdapat pada penelitian yang dilakukan Cahyanto, dkk (2016) dimana aspek psikomotorik menunjukkan nilai berhasil pada siklus I maupun siklus II.

Empat artikel utama dalam penelitian ini menggunakan pendekatan yang hampir sama dalam memaksimalkan peran handout untuk meningkatkan prestasi siswa. Penelitian yang dilakukan Andre Reza Islamic, J.S. Sukardjo, dan Nanik Dwi Nurhayati (2016) menggunakan metode Team Assisted Individualization (TAI) dan handout, dengan pembentukan siswa ke dalam beberapa kelompok dengan adanya siswa yang ditunjuk menjadi asisten berdasarkan hasil pretest yang diberikan di pertemuan awal. Siswa diberikan kesempatan untuk berdiskusi, kemudian terdapat sesi presentasi oleh setiap kelompok yang akan ditanggapi oleh kelompok lain. Peran guru dalam metode ini lebih kepada penguatan materi melalui pemberian pemahaman mengenai materi yang kurang tepat yang disampaikan kelompok. Pada akhir pelajaran, guru bersama dengan siswa menyimpukan hasil yang didapatkan untuk kemudian dilakukan penilaian untuk mengetahui tingkat ketercapaian siklus I. Pada siklus II asisten kelompok diharapkan memberikan pemahaman kepada siswa lain. 
Hasilnya terdapat peningkatan ketercapaian siswa dalam aspek kognitif maupun afektif dimana aspek kognitif yang sebelumnya berada pada tingkat ketercapaian $42,11 \%$ meningkat menjadi $63,16 \%$ melebihi target $60 \%$. Sementara pada aspek afektif meningkat dari $70,24 \%$ menjadi $74,47 \%$.

Penelitian yang dilakukan Enggar Mawarni, Bakti Mulyani, dan Sri Yamtinah (2015) menggunakan Peer Tutoring dengan didukung animasi macromedia flash dan handout. Pada penelitian ini juga lebih ditekankan diskusi dan kerja sama antar siswa dalam kelompok, dengan satu orang dalam kelompok yang ditunjuk untuk membantu teman-temannya. Terdapat dua siklus dalam penelitian ini, dengan posisi siklus II sebagai perbaikan dari kekurangan atau kendala yang terdapat pada siklus I. Hasil penelitian menunjukkan bahwa terdapat peningkatan dari siklus I ke siklus II dimana pada siklus II seluruh aspek tercapai bahkan pada aspek afektif tingkat ketercapaian $100 \%$.

Penelitian yang dilakukan Muhammad Agung Safari Cahyanto, Suryadi Budi Utomo, dan Sri Yamtinah (2016) menggunakan model Cooperative Problem Solving (CPS) yang dilengkapi handout. Pada penelitian ini guru memberikan pertanyaan mengenai materi untuk melihat keaktifan siswa yang kemudian dibagi menjadi beberapa kelompok untuk kemudian diberikan waktu membaca materi. Guru kemudian memberikan soal untuk didiskusikan dalam kelompok dan hasil diskusi disampaikan ke depan untuk dibandingkan dengan kelompok lain. Pada akhir siklus I ini diberikan postest untuk mengukur tingkat ketercapaian pembelajaran. Hasil evaluasi kemudian menjadi bahan perbaikan pada siklus II dan pada siklus II hanya berfokus pada aspek kognitif yang belum tuntas. Hasilnya terdapat peningkatan dari ketiga aspek yaitu kognitif, afektif, dan psikomotorik dimana pada siklus II, seluruh aspek tersebut mampu mencapai tingkat ketercapaian minimal $75 \%$.
Penelitian yang dilakukan Erna Agustina, Agung Nugroho C.S, dan Sri Mulyani menggunakan metode Jingsaw dan handout. Pada metode ini, peran guru lebih memantau jalannya diskusi yang dilakukan siswa berdasarkan materi yang telah ditentukan sebelumnya. Penilaian berdasarkan pada soal yang terdapat pada handout yang kemudian menjadi bahan evaluasi dalam perncanaan siklus II. Hasil penelitian menunjukkan bahwa terdapat peningkatan aspek kognitif dan afektif terutama aspek kognitif yang mengalami peningkatan dari $17,78 \%$ menjadi $77,8 \%$.

Hasil penelitian dari empat artikel utama menunjukkan adanya peningkatan dari siklus I ke siklus II dimana siswa mampu mencapai setiap target ketercapaian. Secara garis besar, metode yang digunakan dalam empat penelitian adalah sama yaitu guru lebih berperan sebagai fasilitator dan siswa dibagi menjadi beberapa kelompok dengan salah satu siswa dalam kelompok menjadi asisten atau tutor untuk membantu teman satu kelompoknya. Setiap kelompok melakukan diskusi dan hasil diskusi disampaikan ke depan kelas untuk dipresentasikan yang kemudian ditanggapi oleh kelompok lain dan peran guru lebih kepada meluruskan apabila terdapat kesalahan dalam penyampaian.

Penggunaan diskusi dalam pembelajaran dapat meningkatkan pemahaman siswa termasuk jiwa kritis siswa dalam pembelajaran yang dapat menunjang hasil belajar dengan adanya peningkatan miant belajar (Ardianto et al., 2019) (Nisa et al., 2018). Perlu adanya tutor, mentor, atau asisten dalam sebuah kelompok diskusi yang dapat memandu diskusi dalam kelompok dan memberikan pemahaman dengan baik. Meskipun demikian, guru juga berperan dalam diskusi yang dilakukan untuk memberikan pemahaman atau teori dengan baik termasuk meluruskan apabila terdapat kesalahan yang diberikan siswa. Peran dan metode diskusi yang tepat tentu dapat meningkatkan pemahaman siswa yang mengarah kepada peningkatan hasil belajar siswa (Sistyarini \& Nurtjahyani, 2017). 
Handout sebagai bahan diskusi dan sumber materi dalam melaksanakan diskusi berperan penting dalam menciptakan hasil yang efektif sesuai dengan target ketercapaian. Sehingga materi yang terdapat dalam handout juga berperan dalam menentukan seberapa efektif handout dalam meningkatkan hasil belajar atau prestasi siswa (R. Ulya et al., 2016). Selain itu penggunaan media seperti video juga dinilai berkontribusi dalam menunjang ketercapaian prestasi siswa. Hal tersebut disebabkan video mampu menarik perhatian siswa sehingga akan meningkatkan minat belajar siswa dan merangsang otak untuk dapat memahami setiap materi yang disampaikan (Pratama \& Sakti, 2020).

Penggunaan handout sebagai media pembelajaran yang dipadukan media video dinilai memberikan dampak yang lebih besar dalam meningkatkan hasil belajar siswa. Selain itu metode diskusi yang tepat dengan disesuaikan sasaran akan memberikan dampak yang lebih efketif. Hal tersebut disebabkan tahapan dari diskusi harus mampu menarik minat dari siswa dan sesuai kemampuan agar mampu memberikan hasil yang sesuai target. Perpaduan metode dan bahan pembelajaran yang tepat akan memberikan dampak yang efektif dalam meningkatkan hasil belajar dan prestasi siswa. Metode diskusi dengan ditunjang handout dan video sebagai bahan pembelajaran dapat meningkatkan hasil belajar dan prestasi siswa sesuai dengan target pembelajaran.

\section{SIMPULAN DAN SARAN}

Berdasarkan jabaran di atas, maka kesimpulan yang dapat diambil adalah handout dapat digunakan sebagai alternatif pembelajaran kimia di sekolah, karena adanya handout sebagai bahan ajar diidentifikasi mampu meningkatkan minat belajar serta frekuensi aktivitas belajar siswa. Handout efektif dalam meningkatkan prestasi siswa, melalui mekanisme peningkatan pemahaman, literasi dan keterampilan berpikir kritis siswa yang dicapai jika dibandingkan dengan pembelajaran tanpa handout. Perpaduan metode diskusi dan penggunaan handout serta video sebagai media pembelajaran dapat meningkatkan hasil belajar atau prestasi siswa dengan lebih efektif.

\section{DAFTAR RUJUKAN}

Agustina, E., Saputro, A., \& Mulyani, S. (2013). Penggunaan Metode Pembelajaran Jigsaw Berbantuan Handout Untuk Meningkatkan Aktivitas Dan Prestasi Belajar Siswa Pada Materi Pokok Hidrokarbon Kelas Xc Sma Negeri 1 Gubug Tahun Ajaran 2012/2013. Jurnal Pendidikan Kimia Universitas Sebelas Maret. 2(4), 66-71.

Ardianto, A., Susilawati, S., \& Rasmiwetti, R. (2019). Development of Guided Inquiry-Based Chemical Handout in Buffer Solution Materials for Senior High School. Journal of Educational Sciences. 3(3), 364-376

Astuti, D., Saputro, S., \& Mulyani, S. (2016). Pengembangan Modul Kimia Berbasis Scientific Approach Pada Materi Ikatan Kimia Kelas X SMA/MA Semester 1. Inkuiri. 5(2), 71-78.

Azmy, M. K., Purwoko, A. A., \& Hadisaputra, S. (2018). The Development Of Chemistry Teaching Materials In The Form Of HandoutsBased ( PBL ) In Class XI IPA Madrasah Aliyah ( Ma ) Kediri District. IOSR Journal of Research \& Method in Education (IOSR-JRME). 8(3), 71-73.

Bhabiet, L., Accraf, R., Khery, Y., Kimia, P. P., Mataram, I., \& No, J. P. (2018). Pengembangan E-Modul Interaktif Berbasis Android dan Nature Of Science Pada Materi Ikatan Kimia dan Sains Siswa Skor Rata- Skor Rata- Peringka a I ndonesia Internasional karakter ilmiah. Memahami Nature of Science (NOS) merupakan bagian penting dari li. Hydrogen: Jurnal Kependidikan Kimia. 6(2). 
Cahyanto, M., Utomo, S., \& Yamtinah, S. (2016). Penggunaan Model Pembelajaran Cooperative Problem Solving (Cps) Dilengkapi Handout Untuk Meningkatkan Kemampuan Berpikir Kritis Dan Prestasi Belajar Siswa Materi Termokimia Kelas Xi Ipa Semester Ganjil Sma N 3 Boyolali Tahun Pelajaran 2015/2016. Jurnal Pendidikan Kimia Universitas Sebelas Maret. 5(4), 43-50.

Fatma, Holiwarni, B., \& Susilawati. (2016). the Development of a Comprehensive Intelligence Handout Charged for the Reaction Rate Material on the Grade $\mathrm{Xi}$ High School. Jurnal Online Mahasiswa Fakultas Keguruan Dan Ilmu Pendidikan Universitas Riau. 1(1), 111.

Habibati, H., Nazar, M., \& Septiani, P. D. (2019). Pengembangan Handout Berbasis Literas Sains Pada Materi Larutan Elektrolit dan Nonelektrolit. Jurnal IPA \& Pembelajaran IPA. 3(1), 43-48.

Herawati, N. S., \& Muhtadi, A. (2018). Pengembangan modul elektronik (emodul) interaktif pada mata pelajaran Kimia kelas XI SMA. Jurnal Inovasi Teknologi Pendidikan. 5(2), 180-191.

Humaira, H., Saputro, S., \& Setyowati, W. A. E. (2019). Studi Komparasi Metode Pembelajaran Kooperatif Student Teams Achievement Division (STAD) dan Numbered Head Together (NHT) Berbantuan Media Handout terhadap Prestasi Belajar Siswa Materi Sistem Periodik Unsur Kelas X SMA Negeri 2 Sukoharjo. Jurnal Pendidikan Kimia. 8(2), 299.

Irfandi, I., Linda, R., \& Erviyenni, E. (2018). Pengembangan Modul Pembelajaran Kimia Berbasis Learning Cycle - 5E pada Materi Ikatan Kimia. EduChemia (Jurnal Kimia Dan Pendidikan). 3(2), 184.

Islamic, A., Sukardjo, J., \& Nurhayati, N. (2016). Penerapan Metode
Pembelajaran Team Assisted Individualization (Tai) Dilengkapi Media Handout Untuk Peningkatkan Prestasi Belajar Dan Interaksi Sosial Siswa Pada Materi Pokok Tata Nama Senyawa Kimia Dan Persamaan Reaksi Kimia Kelas X2 SMA Negeri Gondangrej. Jurnal Pendidikan Kimia. 5(2), 68-74.

Jayadiningrat, M. G., \& Ati, E. K. (2018). Peningkatan Keterampilan Memecahkan Masalah Melalui Model Pembelajaran Problem Based Learning (Pbl) Pada Mata Pelajaran Kimia. Jurnal Pendidikan Kimia Indonesia. 2(1), 1.

Lubis, I. R., \& Ikhsan, J. (2015). Pengembangan Media Pembelajaran Kimia Berbasis Android Untuk Meningkatkan Motivasi Belajar Dan Prestasi Kognitif Peserta Didik Sma. Jurnal Inovasi Pendidikan IPA. 1(2), 191.

Muwarni, E., Mulyani, B., \& Yamtinah, S. (2015). Penerapan Peer Tutoring Dilengkapi Animasi Macromedia Flash Dan Handout Untuk Meningkatkan Motivasi Berprestasi dan Prestasi Belajar Siswa Kelas XI IPA 4 SMAN 6 Surakarta Tahun Pelajaran 2013/2014 pada Materi Kelarutan dan Hasil Kali Kelarutan. Jurnal Pendidikan Kimia (JPK). 4(1), 29-37.

Nisa, B., Andayani, Y., \& Setiadi, D. (2018). Development of Chemical Instruments ( Handout ) Model of Findings Based On KAPRA Class X SMA / Ma. IOSR Journal of Research \& Method in Education (IOSR-JRME). 8(3), 68-70.

Norjana, R., \& Joharmawan, R. (2016). Identifikasi Tingkat Pemahaman Konsep Hukum-hukum Dasar Kimia dan Penerapannya dalam Stoikiometri pada Siswa Kelas X IPA di MAN 3 Malang. Jurnal Pembelajaran Kimia (J-PEK). 01(2), 42-49.

Pratama, D. P. A., \& Sakti, N. C. (2020). 
Pengembangan Media Pembelajaran Handout Digital Berbasis Android Pada Materi APBN dan APBD Kelas XI IPS. Jurnal Pendidikan Ekonomi Undiksha. 1(1), 43-53.

Rachmatia, E., Aunurrahman, \& Usman, A. (2016). Pengembangan Modul Pembelajaran Kimia untuk Kecakapan Membangun dan Menggunakan Konsep Redoks dan Hidrokarbon Kelas X SMAN 3 Sungai Kakap. Journal Of Prospective Learning. 1(2), 20-31.

Rahma, A. N. (2012). Pengembangan Perangkat Pembelajaran Model Inkuiri Berpendekatan Sets Materi Kelarutan Dan Hasil kali Kelarutan Untuk Menumbuhkan Keterampilan Berpikir Kritis Dan Empati Siswa Terhadap Lingkungan. Journal of Educational Research and Evaluation. 1(2).

Rinaningsih, Kadarohman, A., Firman, H., \& Suyatno. (2016). Penerapan Metode Pembelajaran Pondok Pesantren dalam Perkuliahan Kimia Organik Materi Mekanisme Reaksi SN1 Dan SN2. Prosiding Seminar Nasional Kimia Dan Pembelajarannya, September, 104108.

Salfrika, A. T. (2016). Pengembangan handout berbasis kontekstual pada materi faktor- faktor yang mempengaruhi laju reaksi untuk sma / ma kelas XI IPA. Jurnal Ilmiah Mahasiswa Pendidikan Kimia (JIMPK). 2(3), 17-26.

Sari, S. A., \& Putri, S. N. (2020). Pengembangan Handout Materi Sistem Koloid Berbasis Guided Note Taking Untuk Meningkatkan Hasil Belajar Dan Respon Siswa Kelas Xi Sma. JIPI (Jurnal IPA Dan Pembelajaran IPA). 4(1), 41-59.

Sari, S.A., Jasmidi., Kembaren, A., Sudrajat, A. 2018. The Development Of Handout Based On Guided Note Taking To Improve The Quality Of Analytical Chemistry Learning.
PEOPLE: International Journal of Social Sciences. 4(3), 720-734.

Saufi, A., \& Hambali. (2019). Menggagas Perencanaan Kurikulum Sekolah Unggul. Al Tanzim: Jurnal Manajemen Pendidikan Islam. 3(1), 44-56.

Septryanesti, N., \& Lazulva, L. (2019). Desain Dan Uji Coba E-Modul Pembelajaran Kimia Berbasis Blog Pada Materi Hidrokarbon. JTK (Jurnal Tadris Kimiya). 4(2), 202215.

Shofwunnada, Nirwana, R.R, Hakim, F. 2018. The Development Of Chemistry Handout Based On Unity Of Sciences Principles For The Chapter Of Acid And Base Materials. Unnes Science Education Journal. 7(1), 69-75.

Sistyarini, D. I., \& Nurtjahyani, S. D. (2017). Analisis Validitas Terhadap Pengembangan Handout Berbasis Masalah pada Materi Pencemaran Lingkungan Kelas VII SMP/MTS. Proceeding Biology Education Conference. 14(1), 581-584.

Subiyanto, S., \& Siregar, T. (2018). Pengembangan Modul Pembelajaran Kimia Pada Materi Sistem Periodik Unsur Berbasis Kearifan Lokal Papua Peserta Didik Kelas X Sma Negeri 4 Jayapura. Jurnal Ilmu Pendidikan Indonesia. 6(3), 71-82.

Sulastri, S., Nazar, M., \& Adiska, D. N. (2018). Pengembangan Hand-Out Konsep Larutan Berintegrasi Nilai Religi Untuk Meningkatkan Minat Belajar Siswa Sma Pada Pondok Pesantren Terpadu. Jurnal Pendidikan Sains Indonesia. 6(2), 95-100.

Sulastry, T., \& Jusniar. (2011). Pengembangan Perangkat Pembelajaran Kimia Berbasis COntekstual Teaching and Learning pada Materi Pokok Laju reaksi. Jurnal Chemica. 12(2), 59-68.

Tiring, sri sulystya N., Saputro, S., \& Utomo, S. B. (2015). Pengembangan 
modul kimia berbasis inkuiri terbimbing pada materi identifikasi gugus fungsi kelas $\mathrm{x}$ smk kimia industri. Jurnal Inkuiri. 4(3), 51-59.

Ulya, H., Rudibyani, R. B., \& Efkar, T. (2018). Pengembangan Modul Kimia Berbasis Problem Solving Pada Materi Asam Basa Arrhenius. Jurnal Pendidikan Dan Pembelajaran Kimia. 7(1), 129-141.

Ulya, R., Sari, S. A., \& Ismayani, A. (2016). Pengembangan Handout Berbasis Guided Note Taking Pada Materi Koloid Kelas XI MAN Banda Aceh 1 Tahun Pelajaran 2015/2016. Jurnal Ilmiah Mahasiswa Pendidikan Kimia (JIMPK). 1(4), 115-124.

Wati, L., \& Fatisa, Y. (2018). Desain Bahan Ajar Berupa Handout Berbasis Inkuiri Terbimbing Pada Pembelajaran Kimia Materi Hidrokarbon. Konfigurasi: Jurnal Pendidikan Kimia Dan Terapan. 1(2), 219.

Yerimadesi, Y., Bayharti, B., Handayani, F., \& Legi, W. F. (2017). Pengembangan Modul Kesetimbangan Kimia Berbasis Pendekatan Saintifik Untuk Kelas Xi Sma/Ma. Sainstek: Jurnal Sains Dan Teknologi. 8(1), 85.

Yerimadesi, Y., Putra, A., \& Ririanti, R. (2017). Efektivitas Penggunaan Modul Larutan Penyangga Berbasis Discovery Learning Terhadap Hasil Belajar Siswa Kelas Xi Mia Sman 7 Padang. Jurnal Eksakta Pendidikan (Jep). 1(1), 17.

Yusutria. (2017). Profesionalisme Guru Dalam Meningkatkan Kualitas Sumber Daya Manusia. Jurnal Curricula. 2(1), 40.

Zulvianda, H., Hanum, L., \& Nazar, M. (2016). Pengembangan E-Module Kimia SMA Pada Materi Larutan Elektrolit dan Non Elektrolit. Jurnal Ilmiah Mahasiswa Pendidikan Kimia. 1(3), 9-16. 